\title{
Invasive plants as catalysts for the spread of human parasites
}

\author{
Richard N. Mack, Melissa C. Smith \\ School of Biological Sciences, Washington State University, Pullman, WA 99164 USA \\ Corresponding author: Richard N. Mack (rmack@wsu.edu)
}

Academic editor: Ingolf Kühn | Received 20 February 2011 | Accepted 27 June 2011 | Published 11 August 2011

Citation: Mack RN, Smith MC (2011) Invasive plants as catalysts for the spread of human parasites. NeoBiota 9: 13-29. doi: $10.3897 /$ neobiota.9.1156

\begin{abstract}
To a degree not widely recognized, some naturalized and invasive plants increase the risks to human health by enhancing the proliferation of vectors of virulent human parasites. These potential risks are restricted by neither ecosystem nor geography. The dense, floating mats of the tropical South American invasive macrophyte Eichhornia crassipes (water hyacinth) creates habitat for larvae of the dipteran vectors of Plasmodium spp., the causative agents of malaria, and other parasites. In Africa, the South American shrub Lantana camara (lantana) provides suitable habitat in otherwise treeless areas for dipteran vectors (Glossina spp.) of protozoans (Trypanosoma spp.) that cause trypanosomiasis. In the eastern United States, proliferation of the invasive Berberis thunbergii provides questing sites for the blacklegged ticks that carry the spirochete Borrelia burgdorferi, the causative agent of Lyme disease. Unanticipated health consequences will likely continue to emerge from new plant introductions. Hantaviruses are rodent-borne parasites that cause lethal hemorrhagic fevers in humans. Populations of rodent Hantavirus vectors in South America increase rapidly in response to fruit availability among masting, native bamboos. In the United States the omnivorous deer mouse Peromyscus maniculatus also carries Hantavirus (Sin Nombre Virus). The on-going escape of Asian frost-tolerant bamboos from cultivation raises the possibility of their becoming invaders - several have already become naturalized - and in turn providing a temporary food source for populations of infected native rodents. Proposed introductions of floating aquatic vascular species, species with masting reproduction and species that could occupy an unfilled niche in a new range deserve careful evaluation as catalysts of unintended species interactions, especially of human parasites.
\end{abstract}

\section{Keywords}

bamboos, disease, hantavirus, malaria, quarantine, schistosomiasis, trypanosomiasis, vectors 


\section{Introduction}

Deliberate plant introductions often produce unexpected, but decidedly negative, consequences in their new range. Most attention is directed currently at immigrant species that become naturalized or even invasive (sensu Mack et al. 2000), i.e., exerting effect over a new range by usurping the role of native plants (or valued non-native species) through competition (Flory and Clay 2010), altering the water or fire regime (D’Antonio 2000), impeding navigation (Gopal 1987) or disrupting mutualisms (Richardson et al. 2000). These consequences can have simultaneously a strong economic as well as environmental component (Pimentel et al. 2000; Pimentel 2002).

Examples in which the introduced species jeopardizes the health of vertebrates, including humans (Burrows and Tyre 2001), form a category of naturalizations/invasions that are viewed with special concern. These species can act by either causing severe contact dermatitis (Heracleum mantegazzianum, Pyšek et al. 2007) or debilitating respiratory trauma (Parthenium hysterophorus, Parsons and Cuthbertson 1992), or the production of toxins that are fatal if ingested (Bryonia alba, Datura stramonium, Nerium oleander) (Turner and Szczawinski 1991). Much deserved attention has been directed at identifying, prohibiting the transport, and controlling outbreaks of poisonous plants in new ranges (e.g. Plant Protection Act, USDA 2000). Consequently, the risk of new introductions of toxin-producing species has fallen (Westbrooks 1981).

We propose here a further, largely unrecognized, category of persistent introduced plants for which their negative consequences had not been foreseen: those that serve as indirect catalysts for the transmission of human parasites. In these cases, far from bringing about a perceived beneficial effect (e.g. fuel, food, forage, medicine), the introduced plants exacerbate the incidence of human suffering. Our initial examples involve previously reported interactions of introduced plants, vectors and parasites. In our final example, we contend that the current introduction of leptomorphic bamboos could increase the incidence of a highly lethal disease (Hantavirus Pulmonary Syndrome) in North America and elsewhere.

\section{Introduced aquatic macrophytes: facilitation by Eichhornia crassipes of the dipteran and snail vectors of human parasites}

Water hyacinth (E. crassipes) (Pontederiaceae) is a widely introduced macrophyte that is a serial invader in the tropics and subtropics and is even naturalized at temperate latitudes (Holm et al. 1977, Gopal 1987, Barrett 1989). E. crassipes is often termed "one of the world's worst weeds" (Holm et al. 1977) or even "the world's worst weed' (Cook 1990) - epithets that invoke sizeable biome bias, as the plant requires freshwater environments above $5^{\circ} \mathrm{C}$ (Owens and Madsen 1995). Nevertheless, the damage it inflicts can be undeniably massive to aquatic communities and humans dependent on these freshwater ecosystems for food, transportation (Gopal 1987) and potable water (Mailu 2001). 
The invasion by water hyacinth of communities fringing Lake Victoria and its connected rivers best illustrate the damage this plant has wrought. From its early detection in Lake Victoria in 1989 (Twongo 1993), the invader spread mainly through the production of ramets around the lakeshore; it occupied as much as $80 \%$ of the shoreline in Uganda alone (Mailu 2001). At the maximum measured extent of E. crassipes in 1998, it had occupied more than $17,000 \mathrm{~h}$ and likely much more (Albright et al. 2004). Julien (2008) estimates that under ideal growing conditions (and assuming unlimited ability for the population to spread radially) an initial two $\mathrm{kg}$ of water hyacinth could produce 16 tonnes of plant material after six months!

As part of a litany of environmental/economic costs, water hyacinth facilitates the incidence of human disease by increasing the habitat for aquatic dipterans, particularly those anopheline mosquitoes that carry the causative agents for malaria (Plasmodium spp.). A link between water hyacinth and the incidence of malaria has been recognized for decades (e.g. Barber and Hayne 1925, Meyer 1947, Gopal 1987 and references therein), although the clear experimental evidence, e.g., side-by-side trials with water hyacinth and native lakeshore vegetation, has apparently yet to be performed. The stagnation or reduction in water current by large mats of water hyacinth appears key here, by allowing Anopheles females to lay eggs (Merritt et al. 1992). The growth habit of $E$. crassipes with its short stolons and dense concentrations of ramets, long petioles, and a fibrous root system substantially impedes water current along a shoreline. Unlike its congener, Eichhornia azurea, water hyacinth can grow rapidly without roots attached to the underlying sediment (Barrett 1989). Although the protozoans that cause malaria resided in the Lake Victoria watershed long before the early $20^{\text {th }}$ century arrival of water hyacinth (Clyde 1967), water hyacinth has increased the incidence of these parasites by greatly increasing habitat for Anopheles spp. (Gopal 1987, Feikin et al. 2010). Furthermore, the concentration of people living alongside a body of freshwater exacerbates disease incidence by providing a large group of susceptible hosts (Morse 1995) (Fig. 1).

Tragically, the habitat created by water hyacinth not only facilitates anopheline mosquitoes but can also create habitat for snails in the genera Biomphalaria and Bulinus, hosts for the flukes that cause schistosomiasis (bilharzia), and dipteran vectors (e.g. Mansonia spp.), of the nematodes that cause filariasis. The snails derive resting sites as well as food (algae and detritus) within mats of water hyacinth (Mitchell 1974). Ofulla et al. (2010) found that the vectors Biomphalaria sudanica and Bulinus africanus were preferably attached to E. crassipes in Lake Victoria, even becoming attached to water hyacinth in greater numbers than to the native hippo grass (probably Vossia cuspidata).

Adults of several Mansonia spp. infect humans with the nematode Brugia malayi, the causative agent of lymphatic filariasis (Roberts and Janovy 2009). The association of Masonia spp. and water hyacinth in Southeast Asia is particularly extensive: all stages in the mosquito's development rely on the plant. Egg masses are commonly laid on the plant's young semi-submerged leaves. Later the larvae and pupae of $M$. uniformis, for example, swim to the plant's roots and become tightly attached to the fibrous roots (Burton 1960). The larvae must attach their siphons to E. crassipes to acquire $0_{2}$ (Chandra et al. 2006). 


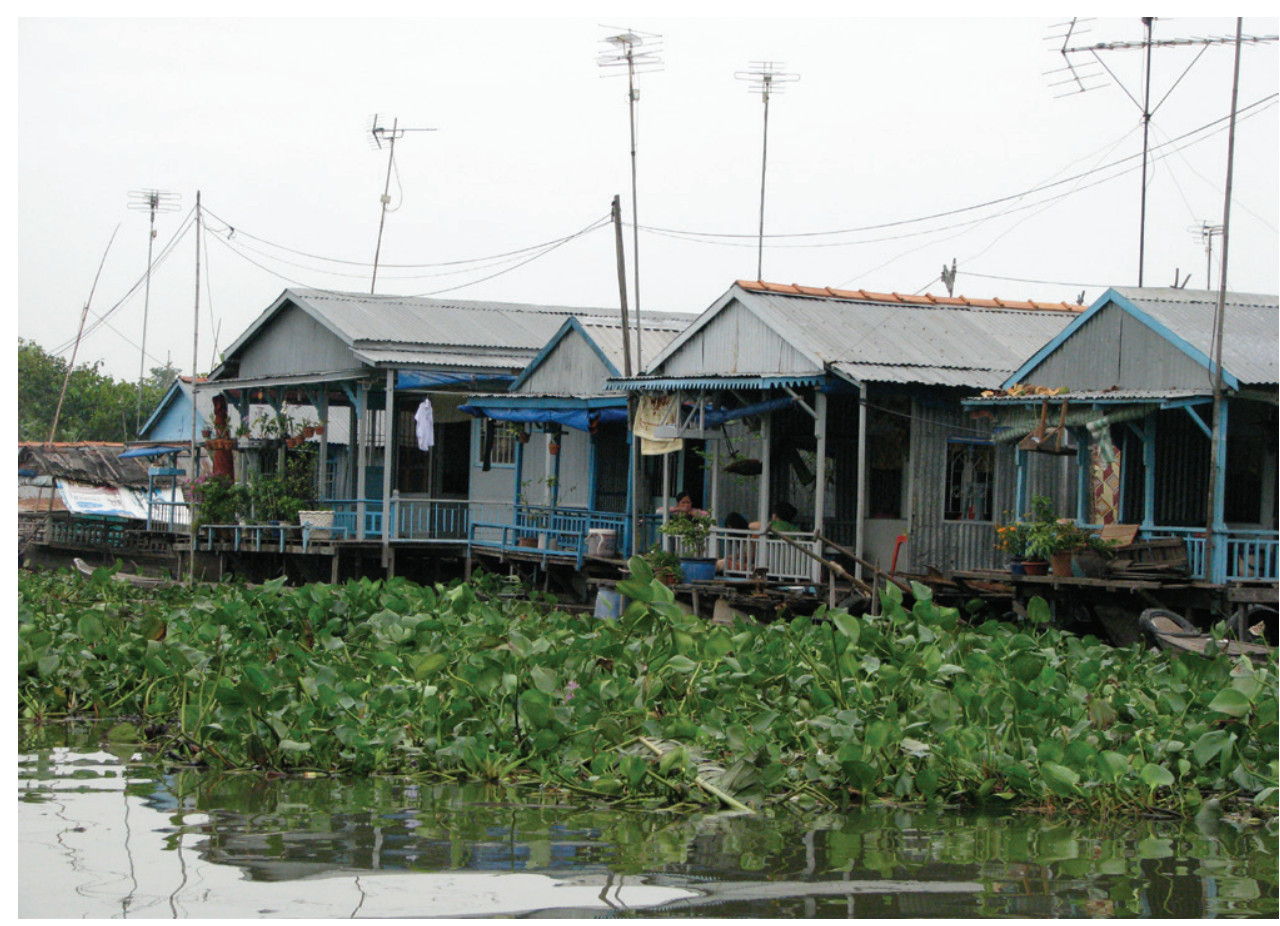

Figure I. Eichhornia crassipes (water hyacinth) is widely distributed in waterways in the tropics and subtropics. The ability of its mass of fibrous, free-floating roots and semi-submerged leaves and stems to decrease water current increases habitat for anopheline mosquitoes, vectors for Plasmodium spp. As a result, its close association with human settlements often leads to an increase in vector-borne diseases, including malaria. Mekong River, at Viet Nam-Cambodia border. (Photo: RN Mack).

Water hyacinth has also been implicated in harboring the causative agent for cholera, Vibrio cholerae. Feikin et al. (2010) found a direct correlation from 1994-2008 in the incidence of reported cases of cholera in Nyanza Province, Kenya, which borders Lake Victoria, and the extent of the adjacent lakeshore occupied by E. crassipes. Two surges in the number of cases of cholera in Nyanza Province coincide with two pulses in the abundance of water hyacinth (1997-2000 and 2006-2008) - significantly more infections per capita than in Kenya as a whole. As they point out, correlation does not however demonstrate causation, especially as other factors could confound the results, including the incomplete reporting of cholera cases. They hypothesize that water hyacinth, rather than serving as a refuge for $V$. cholerae-carrying copepods, may instead provide a direct nidus for the bacterium, especially in its fibrous roots - a contention supported by experimental evidence (Spira et al. 1981). Alternatively, a shoreline packed with $E$. crassipes may concentrate contaminated sewage close to shore, thereby increasing the opportunity for infection, regardless of the bacterium's direct attachment to water hyacinth (Rejmáková et al. 2006).

Attempts to combat water hyacinth in new ranges have been waged for more than a century. Specific legislation authorizing the dredging or poisoning of water hyacinth 
in Florida was enacted by the U.S. Congress in the late 1890 s - to no avail (Klorer 1909). The identification and release of biological control agents (the weevils, Neochetina bruchi and Neochetina eichhorniae) in Lake Victoria from 1995 onward had successfully reduced the extent of water hyacinth mats by 2000 (Wilson et al. 2007). Nevertheless Julien (2008, p. 477) presents a grim view of the ability to remove a large infestation of water hyacinth, "Once it is established, it is impossible to eradicate," although he views its integrated management as feasible. In short, the damage that water hyacinth inflicts, including its facilitation of the vectors of lethal parasites, shows few signs of abating.

\section{Lantana camara harbors Glossina spp., vectors for trypanosomes}

Plant invaders that facilitate the spread of human parasites are not, of course, restricted to aquatic environments. If E. crassipes is touted as one of the worst invaders in freshwater ecosystems, then Lantana camara (Verbenaceae) must be among its most notorious counterparts on land. This tall shrub $(\leq 5 \mathrm{~m}$ tall) is native to tropical America, although its origins and phylogeny have only recently been clarified (Sanders 2006). L. camara refers to a multi-taxon hybrid swarm created by horticulturists, beginning in the $18^{\text {th }}$ century, augmented by hybridizations within introduced ranges (Stirton 1977, Sanders 2006). Thus, L. camara is in effect the misbegotten product of the desire to create an ever more attractive ornamental plant. Sanders (2006) proposes the cultivars be re-named L. strigocamara. To avoid confusion in citing the epidemiological literature below, we refer here to the cultivar as L. camara.

So attractive and varied are the flowers of $L$. camara that the shrub has been spread and subsequently widely naturalized throughout the tropics and subtropics and can be cultivated even in some temperate locales (e.g. Auckland, New Zealand, RN Mack, personal observation). It is routinely one of the first introduced species encountered upon arriving in many tropical towns and villages, testimony in part to its abundant production of bird-dispersed drupes (Binggeli 2003). The zeal and intensity of its deliberate spread are perhaps best illustrated by the number of remote Pacific islands to which it has been introduced and has become invasive (e.g. Tonga, Pitcairn and Norfolk) (Thaman 1974).

Its link to human disease in Africa, for example, is attributable to its aggressive growth: it forms an impenetrable thicket of sprawling, intertwined (and often spiny) stems on disturbed or otherwise open sites. These thickets provide habitat for Glossina spp. (the tsetse fly), which are carriers of trypanosomes, such as Tripanosoma brucei gambiense; these protozoans cause African trypanosomiasis or African Sleeping Sickness. The World health Organization (WHO 2010) states best the consequences of protracted illness from African trypanosomiasis: "Without treatment, sleeping sickness is considered fatal."

Lantana provides resting sites for adult Glossina flies in addition to sites for larvaposition by Glossina spp. (Ng'ayo et al. 2005) either on the abaxial surface of leaves or 
along small twigs in the intertwining mass of branches. The flies reside principally on the plant $<4 \mathrm{~m}$ above the soil surface (Okoth and Kapaata 1987). Unlike anopheline mosquitoes that search for a blood meal at night, Glossina is active in the day but must seek shade when the temperature $>40^{\circ} \mathrm{C}$ (Hargrove 1994). A wide, open site, such as a cleared forest or savanna, prevents Glossina dispersal (Nash 1969). The planting of lantana hedges to demarcate fields and property boundaries insidiously led to an increase in the incidence of African Sleeping Sickness in Kenya (Van den Berghe as cited in Nash 1969).

The association between Glossina and L. camara is facilitated by the shrub's production of volatiles. Syed and Guerin (2004) showed strong attraction by three Glossina spp. to lantana leaves and lantana leaf extract in wind tunnel trials. They then combined plant product chemistry with investigation of the flies' antennae receptors to identify an aromatic cocktail of two natural plant products most likely responsible for lantana's attraction: 1-octen-3-ol (or octenol), a secondary alcohol that is also produced in human sweat and attracts biting mosquitoes (Ditzen et al. 2008), and $ß$-caryophyllene, a sesquiterpene that occurs as an active ingredient in many plants, including black pepper, cinnamon and oregano (Gertsch et al. 2008). These results are intriguing, although the efficacy of lantana as an attractant needs evaluation in the context of surrounding vegetation that could produce a vast array of competing chemical stimuli for dipterans.

Tragically, human conflict has repeatedly triggered the spread of the Lantana-Glossina-trypanosome assemblage in Africa, as refugees abandon their land and "bush clearing" is suspended in the war zone. In this manner the continual social upheaval during the regime of Idi Amin in Uganda during the 1970s led to an increased incidence of trypanosomiasis (in this case caused by T. b. rhodesiense) (Molyneux 1997). More recent human conflicts in the eastern Congo-Rwanda-Burundi region as well as in West Africa (e.g. Sierra Leone) have sadly created similar opportunities for the proliferation of lantana and consequently for Glossina (Reyntjens 2009).

Even during peacetime, the cultivation of $L$. camara in human settlements can facilitate disease in treeless areas with African Sleeping Sickness. A non-decorative use of lantana in Kenya has been the replacement of native euphorbs with spiny lantana hedges around cattle pens and to demarcate property boundaries; the result was an increase in the incidence of trypanosomiasis (Greathead 1968, Van den Berghe as cited in Nash 1969). The beauty of this perennially flowering shrub can be deadly with local people in East Africa planting - or at least not clearing - it around their rural homes (Okoth 1986). In effect, the human hosts are unknowingly cultivating resting sites for the tsetse fly alongside their dwellings (Willett 1965) - an insidious link between humans' universal desire for decoration (Mack 2001 and references therein) and their susceptibility to a deadly parasite. Furthermore, as cleared forest sites or crop fields have been abandoned, for whatever reason, in West and East Africa, L. camara has been among the most aggressive colonizers and has consequently created low stature shade, which is ideal for Glossina (Baldry 1966). Consequently, recommending the cessation 
of lantana bush-clearing programs because the shrub can be a local source of firewood (Okoth and Kapaata 1987) is misguided at best and grossly negligent at worse.

\section{Berberis thunbergii alters eastern North American forests and increases habitat for Lyme disease vector, Ixodus scapularis}

Not surprisingly, facilitation of the spread of human parasites by invasive plants is not restricted to tropical locales. Among the best-studied examples in temperate environments involves the contraction of Lyme disease, a debilitating inflammatory condition caused by the tick-borne spirochete, Borrelia burgdorferi. Links between invasive shrubs (principally Berberis thunbergii but also non-native Lonicera spp., Lubelczyk et al. 2004), the blacklegged tick (Ixodus scapularis), B. burgdorferi and most importantly the white-tailed deer as well as other mammals, such as the white-footed mouse (Peromyscus leucopus), have been the subject of ecologically comprehensive research (Ostfeld et al. 2006, Williams et al. 2009, Williams and Ward 2010).

Non-native Berberis and Lonicera were introduced pre-1900 to North America as horticultural ornamentals (Mack 1991) and have subsequently spread into forests in the Eastern U.S., often through bird dispersal (Silander and Klepeis 1999 and references therein). Increase in the likelihood of the shrubs' persistence as well as their role outside cultivation has been furthered by their general unpalatability (Silander and Klepeis 1999) or greater resilience to grazing (Schierenbeck et al. 1994), compared to native understory competitors. As the coverage of these medium height shrubs $(<2 \mathrm{~m})$ has increased in forests, so has the incidence of blacklegged ticks, for which the shrubs provide questing sites and maintenance of the high (approximately 90\%) relative humidity, which is conducive to tick survival (Williams and Ward 2010 and references therein). In turn, as the density of deer populations has increased, so has the number of ticks that have become attached to them as they travel through the forests. Tickladen deer potentially form a diabolical dual role in Lyme disease ecology: continually expanding and re-infecting the forest area harboring $B$. burfdorferi through their wideranging movements and selective grazing.

\section{An ominous new threat: rodent-borne parasites facilitated by natural- ized bamboos}

The examples provided above all describe on going, if under-appreciated, cases of plant invaders indirectly enhancing the incidence of human disease. Our attention has been drawn recently to the looming opportunity for a morphologically distinct group of plants, leptomorphic (or running, sensu McClure 1966) bamboos, to be transported to new ranges, and potentially trigger increases in the size of populations of Peromyscus maniculatus (deer mice), a native North American rodent. 
Bamboos are unique among grasses in displaying synchronized flowering (i.e. masts), in which all individuals of a species flower within the same time frame (months to several consecutive years) worldwide and then die (Janzen 1976). The rapid appearance of abundant bamboo seeds can translate into the increase, however temporarily, of populations of seed predators. For example, a population of Rattus rattus can readily gorge on a bamboo seed crop and undergo rapid population increase. After exhausting this temporary food source, the rats disperse in search of food, often coming in contact with humans (Janzen 1976). Outbreaks of rats, sparked by masting bamboos, are well known in rural Asia and South America, and people living in these affected regions subsequently endure a sharp rise in the incidence of infections from rat-borne parasites (Jaksic and Lima 2003, Lalnunmawia et al. 2005).

Growing interest in ornamental bamboos for horticulture in the U.S. has facilitated the introduction of non-native species (American Bamboo Society 2010), including those with pronounced mast flowering cycles (Janzen 1976). Several of these species are now naturalized in the U.S. (USDA 2010) and consequently have already fulfilled the first critical demographic step on the path to becoming invasive. We hypothesized that synchronous flowering/fruiting of a large population of invasive bamboo could initiate a rapid build-up in rodent populations with accompanying increases in parasite transmission, provided the rodents harboring the causative organism feed upon this novel food.

The deer mouse is an omnivorous (e.g. arthropods, seeds, fungi), widespread native rodent in North America and carries multiple human pathogens, including Sin Nombre Virus (SNV), Francisella tularensis (tularemia), Yersinia pestis (plague) and B. burgdorferi (Mills and Childs 1998, Netski et al. 1999, Feldman et al. 2001). Incidence of these diseases rises with increases in rodent populations (Yates et al. 2002). SNV is an especially serious health threat in Western North America: it causes Hantavirus Pulmonary Syndrome (HPS), a frequently fatal hemorrhagic fever $(-35 \%$ mortality rate) (Netski et al. 1999). In this region, humans can readily encounter an infected deer mouse: e.g. 15\% of deer mice trapped in Montana and Washington carry the virus (Pearson and Callaway 2006, Washington State Department of Health 2010), and deer mice often inhabit peridomestic structures (e.g. barns, sheds, granaries)(Douglass et al. 2006). Transmission of SNV to humans occurs primarily through contact with or inhalation of aerosolized urine and feces (Netski et al. 1999).

We evaluated the ability of $P$. maniculatus to survive and reproduce solely on a diet of Asian bamboo (Bambusa distegia) fruits in laboratory feeding trials in comparison to diets of laboratory rat chow and the seeds of two native species, Pinus ponderosa and Festuca idahoenesis. Females fed bamboo seeds reared significantly more pups than those fed lab chow and pine seeds (LS Mean pairwise comparison, $\mathrm{P}=0.016$ and $\mathrm{P}=$ 0.042 respectively). We observed no significant differences in weight per pup at weaning (ANOVA, $\mathrm{F}_{3,18=2.06}, \mathrm{P}=0.1419$ ). With their short and prolific reproductive cycles, P. maniculatus populations could be particularly responsive to a suddenly available food, such as bamboo seeds (Gashwiler 1979).

Our predictions here deal only with the potential for large-scale spread of leptomorphic bamboos with aggressively spreading rhizomes. Coniferous forests along the 
west coast of North America and inland, in which P. maniculatus is common and locally prominent (Converse et al. 2006), may be particularly at risk of invasion by frosttolerant bamboos, given the strong climatic similarity of these bamboos' native range in temperate Asia and the northwest coast of North America. Use of ornamental running bamboos in landscaping is increasing in the region, both in its popularity and in the number of introduced species (American Bamboo Society 2010). An opportunity for these species to become naturalized in North American appears probable. For example, Sasa kurilensis, a dwarf $(<2 \mathrm{~m})$ running bamboo forms a continuous hedge-like layer in Asian coniferous forests that bear many floristic and physiognomic similarities to forests in western North America (Numata 1979, Tsuyuzaki and Kanda 1996) (Fig. 2).

Running bamboo species could greatly increase the numbers of rodents first by providing concealment from predators for them in the forest understory and ultimately by providing abundant food. In a worst-case scenario, a naturalized bamboo population undergoes mass flowering/fruiting on remote public lands, resident $P$. maniculatus populations rapidly increase, driven by the newly available resource, to be followed by bamboo eventually waning as a food source. As a consequence, starving peridomestic P. maniculatus disperse into adjacent human settlements. The well-known difficulty of removing bamboos, given their extensive rhizome and root systems (Whittaker 2005), amplifies the potential seriousness of this public health issue.

\section{Future threats of plant invaders as catalysts for the spread of human parasites}

The opportunity for the inadvertent creation of new plant invasions continues, given our frequent inability to predict the invasive potential of species, other than a growing list of "usual suspects", i.e., those species already banned for importation, based on their record as pests. Assessment of new invaders is daunting (National Research Council 2002): not only is accurately predicting a species' performance in a new range challenging, but any regulatory decision arising from a prediction needs to provide phytosanitary protection without forming a constraint to free trade (Mack et al. 2000). A comprehensive assessment of this topic is beyond the scope of our paper. However, we suggest some general plant functional groups or life forms that merit increased scrutiny as potential catalysts for the spread of human parasites.

Aquatic vascular plants. This category comes as no surprise, given the link between water hyacinth and human disease. As land is flooded through impoundment downstream, a new shoreline is effectively created. Aquatic species already within the watershed are readily transported into the new body of water. Such dispersal has sometimes triggered a rise in the incidence of human disease, e.g. an outbreak of schistosomiasis associated with an invasion of Pistia stratiotes and Ceratophyllum demersum in Lake Volta in Ghana in the 1960s (Paperna 1970). Creation of a new lake may not however immediately lead to an invasion of alien aquatic species (Bond and Roberts 1978). But the potential strongly suggests that early incursions of these species should be care- 


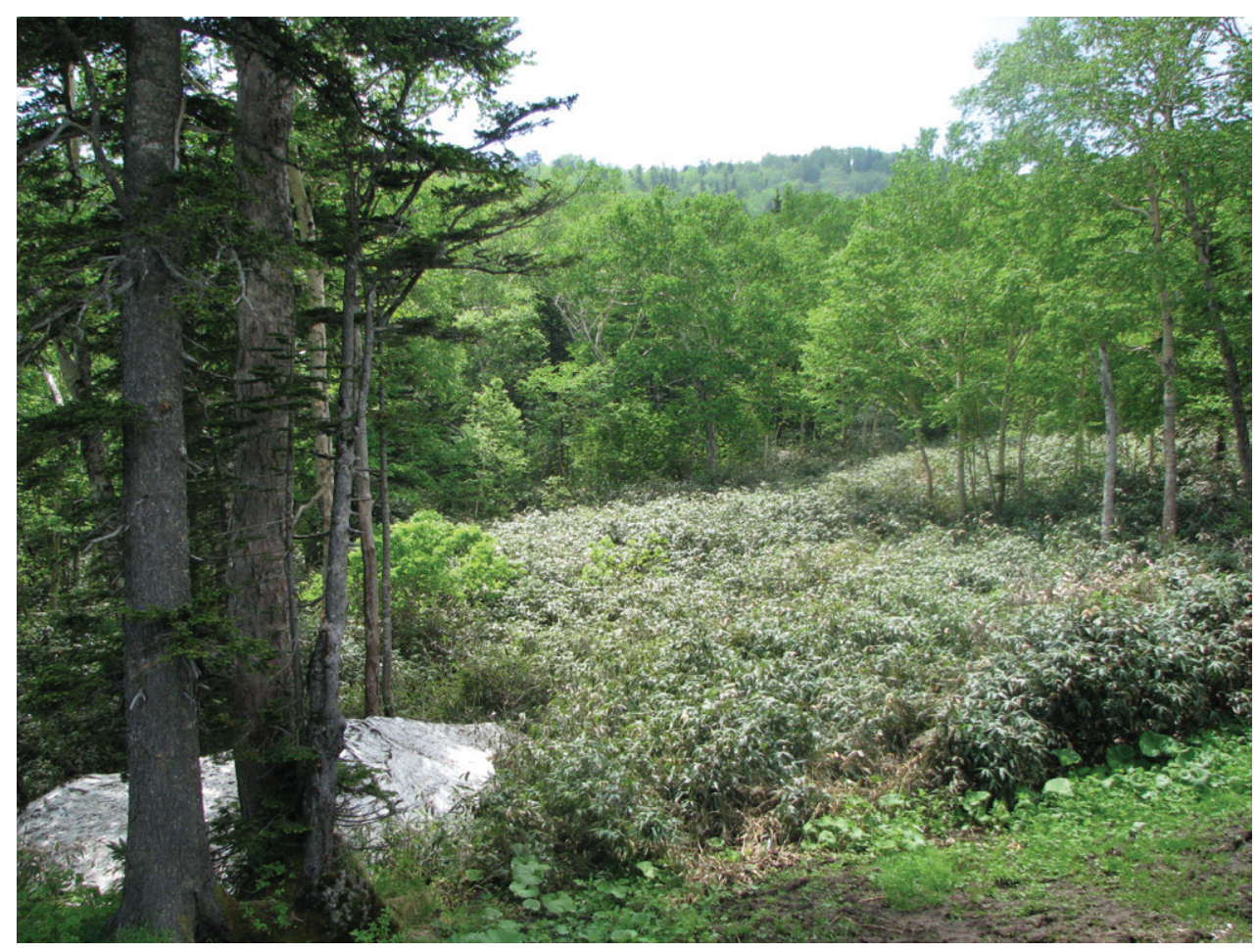

Figure 2. Leptomorphic or running bamboos (e.g. Sasa kurilensis) form prominent swards in the understory of coniferous forests in temperate eastern Asia. As masting species bamboos periodically provide a large, if temporary, food source for rodents that carry human parasites. Depletion of the food commonly drives the rodents into human contact with concomitant rises in human disease. Introduced leptomorphic bamboos could produce similar consequences in North America for Peromyscus maniculatus, a vector of the lethal Sin Nombre Virus (SNV). Daisetsuzan NationalPark, Japan. (Photo: RN Mack).

fully surveyed for negative consequences, if their entry and establishment cannot be prohibited.

Masting species. Bamboos are not the only plants with synchronous reproduction. Masting occurs in many boreal forest conifers (Koenig and Knops 2000) and tropical trees (Sork 1993). Despite the radically different physical environments in which conifers and tropical trees occur, masting has arisen in many woody species; explanations vary but seed satiation remains a likely outcome in many cases (Kelly 1994). Oaks also display masting and provide a well-investigated example of the linkage between seed production and human disease. As noted above, hosts for the blacklegged ticks that carry the causative agent of Lyme disease in the eastern U.S. include the white-footed mouse, P. leucopus. Sizes of these omnivorous rodents' populations rise when acorns are abundant, increasing in turn the density of ticks and eventually the incidence of Lyme disease in humans (Jones et al. 1998). We urge caution (and post-immigration 
field evaluation, Davis et al. 2010) in the introduction of any masting species into a new range.

Absent life forms. Non-native species filling this role form the most taxonomically and morphologically diverse of the categories we believe deserve heightened attention by quarantine services. Many, but by no means most, plant invaders attain their new role by filling a niche unoccupied by a native species (or occupied by a weak native competitor). Examples abound, from the invasion of the European grass Spartina anglica on tidal mud flats along the West Coast of North America to the massive transformation of the Everglades marsh in Florida by the Australian tree, Melaleuca quinquenervia (Mack 2003). Establishment of a novel life form (sensu Raunkiær 1934) invariably creates novel interactions with the native and non-native species, as well as creating opportunities for other immigrant species previously unable to reside in the new range.

The paucity in the native tropical East African flora of large, floating macrophytes that form mats may explain in part the devastating invasion of E. crassipes into so many African waterways. For example, the native flora contains only three species within the Ponteridaceae, Eichhornia natans, Heteranthera callifolia, and Monochoria africana (Verdcourt 1968); none of these species display the unusual morphology of E. crassipes, which is so conducive to forming inter-tangled mats (Barrett 1989). About half a dozen native taxa occur in the East African Nymphaeaceae, another plant family with species that produce floating leaves (Heywood et al. 2007). But here again, none has the growth form that produces an ideal habitat for dipterans (Verdcourt 1989). The question remains of course, whether other aquatic vascular plants, yet to be introduced to East Africa, or other regions with few native macrophytes could duplicate the role now occupied so tenaciously by water hyacinth

\section{Need for further collaboration among epidemiologists, ecologists and quarantine services}

We call attention here to a largely overlooked - or at least inadequately appreciated - link between invasive plants and the incidence of human disease. Exhaustive examination of the biology of human parasites, their vectors and other modes of dispersal and transmission has long been a pillar of field epidemiology worldwide (Simmons et al. 1944, Gregg 2002, Rothman et al. 2008). Consequently, it would be inaccurate to claim that the broader ecological context of disease transmission has been ignored. Instead we alert epidemiologists and ecologists to another category in which their investigations warrant substantial and productive overlap - the search for (and prevention of) new examples in which an immigrant plant species arrives by whatever means in a new range and sparks an increase in human disease and its attendant, preventable suffering. 


\section{Acknowledgements}

We thank J. Kollmann and the other organizers of the 6th European Conference on Biological Invasions (NEOBIOTA) for the opportunity for one of us (RNM) to speak on the theme that led to this paper. We also thank T. Albright, J. Ding, G. Howard, S. Murphy, S. Schooler, R. van Klinken, J. Waage and two anonymous reviewers for helpful suggestions and references and to I. Kühn for the invitation to submit a manuscript for consideration. We thank A.V. Tasker and USDA/APHIS for their support.

\section{References}

American Bamboo Society (2010) Species Source list. http://www.bamboo.org/BambooSourceList/ [accessed 10/14/2010]

Albright TP, Moorhouse TG, McNabb J (2004) The rise and fall of water hyacinth in Lake Victoria and the Kagera River Basin 1989-2001. Journal of Aquatic Plant Management 42: 73-84.

Baldry DAT (1966) Lantana camara as a breeding site for Glossina tachinoides Westwood in south-eastern Nigeria. In: 11th meeting ISCTR, Nairobi, 1966. OAU/STRC Publication 100: 91-93.

Barber MA, Hayne TB (1925) Water hyacinth and the breeding of Anopheles. Public Health Report 40: 2557-2562. doi:10.2307/4577712

Barrett SCH (1989) Waterweed invasions. Scientific American 261: 90-97. doi:10.1038/scientificamerican 1089-90

Bond WJ, Roberts MG (1978) The colonization of Cabora Bassa, Mozambique, a new manmade lake with floating aquatic macrophytes. Hydrobiologia 60: 243-259. doi:10.1007/ BF00011719

Burrows GE, Tyrl RJ (2001) Toxic plants of North America. Iowa State University (Ames, IA), $1342 \mathrm{pp}$.

Burton GJ (1960) Studies on the bionomics of mosquito vectors which transmit filariasis in India. II. The role of water hyacinth (Eichhornia speciosa Kunth) as an important host plant in the lifer cycle of Mansonia uniformis (Theobold) withnotes on the differentiation of the late embryonic and newly hatched stages of Mansonia uniformis (Theobold) and Mansonia annulifera (Theobold). Indian Journal Malariology 14: 81-106.

Chandra G, Ghosh A, Biswas D, Chatterjee SN (2006) Host plant preference of Mansonia mosquitoes. Journal of Aquatic Plant Management 44: 142-144.

Clyde DF (1967) Malaria in Tanzania. Oxford University Press, London, 427 pp.

Converse SJ, Block WM, Williams GC (2006) Small mammal population and habitat responses to forest thinning and prescribed fire. Forest Ecology and Management 228: 263-273. doi:10.1016/j.foreco.2006.03.006

Cook CDK (1990) Origin, autecology and spread of some of the world's most troublesome aquatic weeds. In: Pieterse AH, Murphy KJ (Eds) Aquatic Weeds. The Ecology and Management of Nuisance Aquatic Vegetation. Oxford University Press, Oxford, 31-38. 
D’Antonio C (2000) Fire, plant invasions and global change. In: Mooney HA, Hobbs RJ (Eds) The Impact of Global Change on Invasive Species. Island Press, Covelo, CA, 65-93.

Davis AS, Cousens RD, Hill J, Mack RN, Simberloff D, Raghu S (2010) Screening bioenergy feedstock crops to mitigate invasion risk. Frontiers in Ecology and Evolution 8: 533-539. doi:10.1890/090030

Darlington W (1859) American Weeds and Useful Plants (2 ${ }^{\text {nd }}$ Edition). AO Moore, New York, 460 pp.

Ditzen M, Pellegrino M, Vosshall LB (2008) Insect odorant receptors are molecular targets of the insect repellent DEET. Science 319: 1838-1842. doi:10.1126/science.1153121

Douglass RJ, Semmens WJ, Matlock-Cooley SJ, Kuenzi AJ (2006) Deer Mouse Movements in Peridomestic and Sylvan Settings in Relation to Sin Nombre Virus Antibody Prevalence. Journal of Wildlife Disease 42: 813-818.

Feikin DR, Tabu CW, Gichuki J (2010) Does water hyacinth on East African lakes promote cholera outbreaks? American Journal of Tropical Medicine and Hygiene 83: 370-373. doi:10.4269/ajtmh.2010.09-0645

Feldman KA, Stiles-Enos D, Julia K, Matyas BT, Telford III SR, Chu MC, Petersen LR, Hayes EB (2001) An outbreak of primary pneumonic tularemia on Martha's Vineyard. New England Journal of Medicine 345: 1601-1606. doi:10.1056/NEJMoa011374

Flory SL, Clay K (2010) Non-native grass invasion suppresses forest succession. Oecologia 164: 1029-1038. doi:10.1007/s00442-010-1697-y

Gashwiler JS (1979) Deer Mouse reproduction and its relationship to the tree seed crop. American Midland Naturalist 102: 95-104. doi:10.2307/2425070

Gertsch J, Leonti M, Raduner S, Racz I, Chen JZ, Xie XQ, Altmann KH, Karsak M, Zimmer A (2008) Beta-caryophyllene is a dietary cannabinoid. Proceedings of the National Academy of Sciences 105: 9099-9104. doi:10.1073/pnas.0803601105

Gopal B (1987) Water Hyacinth. Elsevier, Amsterdam, 484 pp.

Greathead DJ (1968) Biological control of Lantana - a review and discussion of recent developments in East Africa. PANS(C) 14: 167-175.

Gregg MB (2002) Field Epidemiology (2 ${ }^{\text {nd }}$ Edition). Oxford University Press, Oxford, 451 pp. Hargrove JW (1994) Reproductive rates of tsetse flies in the field in Zimbabwe. Physiological Entomology 19: 307-318. doi:10.1111/j.1365-3032.1994.tb01057.x

Heywood VH (Ed)(2007) Flowering Plant Families of the World. Firefly, Buffalo, NY, 424 pp. Holm LG, Plucknett DL, Pancho JV, Herberger JP (1977) World Weeds: Natural Histories and Distribution. Wiley, New York, 1152 pp.

Jaksic FM, Lima M (2003) Myths and facts on ratadas: bamboo blooms, rainfall peaks and rodent outbreaks in South America. Austral Ecology 28: 237-251. doi:10.1046/j.14429993.2003.01271.x

Janzen DH (1976) Why Bamboos wait so long to flower. Annual Review of Ecology and Systematics 7: 347-391. doi:10.1146/annurev.es.07.110176.002023

Jones CG, Ostfeld RS, Richard MP, Schauber EM, Wolff JO (1998) Chain reactions linking acorns to Gypsy Moth outbreaks and Lyme Disease risk. Science 279: 1023-1026. doi:10.1126/science.279.5353.1023 
Julien M (2008) Plant biology and other issues that relate to the management of water hyacinth: a global perspective with focus on Europe. OEPP/EPPO Bulletin 38: 477-486.

Klorer J (1909) The water hyacinth problem. Journal of the Association of Engineering Societies 42: 42-48.

Koenig WD, Knops JM (2000) Patterns of annual seed production by Northern Hemisphere trees: a global perspective. American Naturalist 155: 59-69. doi:10.1086/303302

Lalnunmawia F, Jha L, Lalengliana F (2005) Preliminary observations on ecological and economical impacts of bamboo flowering in Mizoram (North East India). Journal of Bamboo and Rattan 4: 317-322. doi:10.1163/156915905775008390

Lubelczyk CB, Elias SP, Rand PW, Holman MS, Lacombe EH, Smith Jr RP (2004) Habitat associations of Ixodes scapularis (Acari: Ixodidae) in Maine. Environmental Entomology 33: 900-906. doi:10.1603/0046-225X-33.4.900

Mack RN (1991) The commercial seed trade: an early disperser of weeds. Economic Botany 45: 257-273. doi:10.1007/BF02862053

Mack RN (2001) Motivations and consequences of the human dispersal of plants. In: McNeely JA (Ed) The Great Reshuffling: Human Dimensions in Invasive Alien Species. International Union for the Conservation of Nature, Cambridge, 23-34.

Mack RN (2003) Phylogenetic constraint, absent life forms and pre-adapted alien plants: a prescription for biological invasions. International Journal of Plant Science 164(3 Suppl): S185-S196. doi:10.1086/368399

Mack RN, Simberloff D, Lonsdale WM, Evans H, Clout M, Bazzaz FA (2000) Biotic Invasions: Causes, Epidemiology, Global Consequences, and Control. Ecological Applications 10: 689-710. doi:10.1890/1051-0761(2000)010[0689:BICEGC]2.0.CO;2

Mailu AM (2001) Preliminary assessment of the social, economic and environmental impacts of water hyacinth in the Lake Victoria Basin and the status of control. In: Julien MH, Hill MP, Center TD, Ding J (Eds) Biological and Integrated Control of Water Hyacinth, Eichhornia crassipes. ACIAR Proceedings 102, Hanoi, 130-139.

McClure FA (1966) The Bamboos ( $1^{\text {st }}$ Edition). Smithsonian Institution Press, Washington, DC, $392 \mathrm{pp}$.

Merritt RW, Dadd RH, Walker ED (1992) Feeding behavior, natural food, and nutritional relationships of larval mosquitoes. Annual Review of Entomology 37: 349-376. doi:10.1146/ annurev.en.37.010192.002025

Meyer SL (1947) Plants of importance in the breeding of Anopheles albimanus Wied. in Panama. Bulletin of the Torrey Botanical Club 74: 257-261. doi:10.2307/2482036

Mills JN, Childs JE (1998) Ecologic studies of rodent reservoirs: their relevance for human health. Emerging Infectious Diseases 4: 529-537. doi:10.3201/eid0404.980403

Mitchell DS (1974) The effects of excessive aquatic plant populations. In: Mitchell DS (Ed) Aquatic Vegetation and Its Use and Control. Unesco, Paris, 50-56.

Molyneux DH (1977) Vector relationships in the Trypanosomatidae. Advances in Parasitology 15: 1-82. doi:10.1016/S0065-308X(08)60526-6

Morse SS (1995) Factors in the emergence of infections diseases. Journal of Infectious Diseases 1: 7-15.

Nash TAM (1969) Africa's Bane. The Tsetse Fly. Collins, London, 224 pp. 
National Research Council, Committee on the Scientific Basis for Predicting the Invasive Potential of Nonindigenous Plants and Plant Pests in the United States (2002) Predicting Invasions of Nonindigenous Plants and Plant Pests. The National Academies Press, Washington, DC, $194 \mathrm{pp}$.

Netski D, Thran BH, St Jeor SC (1999) Sin Nombre Virus pathogenesis in Peromyscus maniculatus. Journal of Virology 73: 585-591.

Ng'ayo NO, Njiru ZK, Kenya EU, Muluvi GM, Osir EO, Masiga DK (2005) Detection of trypanosomes in small ruminants and pigs in western Kenya: important reservoirs in the epidemiology of sleeping sickness? Kinetoplastid Biology and Disease 4: 5-12. doi:10.1186/1475-9292-4-5

Numata M (1979) The Ecology of Grasslands and Bamboolands in the World. VEB Gustav Fisher Erlag, Jena, 299 pp.

Ofulla AVO, Karanja D, Omondi R, Okurut T, Matano A, Jembe T, Abila R, Boera P, Gichuki J (2010) Relative abundance of mosquitoes and snails associated with water hyacinth and hippo grass in the Nyanza gulf of Lake Victoria. Lakes and Reservoirs: Research and Management 15: 255-271. doi:10.1111/j.1440-1770.2010.00434.x

Okoth JO (1986) Peridomestic breeding sites of Glossina fuscipes fuscipes Newst. in Busoga, Uganda, and epidemiological implications for trypanosomiasis. Acta Tropica 43: 283-6.

Okoth JO, Kapaata R (1987) A study of the resting sites of Glossina fuscipes fuscipes (Newstead) in relation to Lantana camara thickets and coffee and banana plantations in the sleeping sickness epidemic focus, Busoga, Uganda. Insect Science and its Application 8: 57-60.

Ostfeld RS, Canham CD, Oggenfuss K, Whitcomb R, Keesing F (2006) Climate, deer, rodents and acorns as determinants of variation in Lyme-disease risk. PLOS Biology 4: 1058-1068. doi:10.1371/journal.pbio.0040145

Owens CS, Madsen JD (1995) Low temperature limits of waterhyacinth. Journal of Aquatic Plant Management 33: 63-68.

Pattison RR, Mack RN (2009) Environmental constraints on the invasion of Triadica sebifera in the eastern U.S.: an experimental field assessment. Oecologia 158: 591-602. doi:10.1007/ s00442-008-1187-7

Paperna I (1970) Study of an outbreak of schistosomiasis in the newly formed Volta Lake in Ghana. Tropenmedizin und Parasitologie 21: 411-425.

Parsons WT, Cuthbertson EG (1992) Noxious Weeds of Australia. Inkata, Melbourne, 698 pp.

Pearson DE, Callaway RM (2006) Biological control agents elevate Hantavirus by subsidizing deer mouse populations. Ecology Letters 9: 443-450. doi:10.1111/j.14610248.2006.00896.x

Penfound WT, Earle TT (1948) The biology of the water hyacinth. Ecological Monographs 18: 447-472. doi:10.2307/1948585

Pimentel D (Ed) (2002) Biological invasions: economic and environmental costs of alien plant, animal, and microbe species. CRC Press, Boca Raton, FL, 384 pp.

Pimentel D, Lach L, Zuniga R, and Morrison D (2000) Environmental and economic costs of nonindigenous species in the United States. BioScience 50: 53-65. doi:10.1641/00063568(2000)050[0053:EAECON]2.3.CO;2 
Pyšek P, Cock MJW, Nentwig W, and Ravn HP (Eds) (2007) Ecology and Management of Giant Hogweed (Heracleum mantegazzianum). CABI, Oxfordshire, 352 pp.

Raunkiær C (1934) Life forms of plants and statistical plant geography. Arno Press, New York, $632 \mathrm{pp}$.

Reyntjens F (2009) The Great African War: Congo and Regional Geopolitics, 1996-2006. Cambridge University Press, Cambridge, 327 pp.

Rejmáková E, Grieco J, Achee N, Masuoka P, Pope K, Roberts D, Higashi RM (2006) Freshwater community interactions and malaria. In: Collinge SK, Ray C (Eds) Disease Ecology: Community Structure and Pathogen Dynamics. Oxford University Press, Oxford, 90-104.

Richardson DM, Allsopp N, D’Antonio CM, Milton SJ, Rejmánek M (2000) Plant invasions - the role of mutualisms. Biological Reviews of the Cambridge Philosophical Society 75: 65-93. doi:10.1017/S0006323199005435

Roberts LS, Janovy J (2009) Gerald D. Schmidt and Larry S. Roberts' Foundations of Parasitology. McGraw Hill, Boston, 659 pp.

Rothman KJ, Greenland S, Lash TL (2008) Modern Epidemiology ( $3^{\text {rd }}$ Edition). Lippincott, Williams and Wilkins, Wolker Kluwer, 258 pp.

Sanders RW (2006) Taxonomy of Lantana sect. Lantana (Verbenaceae): I. correct application of Lantana camara and associated names. Sida, Contributions to Botany 22: 381-421.

Schierenbeck KA, Mack RN, Sharitz RR (1994) Effects of herbivory on growth and biomass allocation in native and introduced species of Lonicera. Ecology 75: 1661-1672. doi:10.2307/1939626

Simmons JS, Whayne TF, Anderson GW, Horack HM (1944) Global Epidemiology A Geography of Disease and Sanitation (Vol 1). Lippincott, Philadephia, 504 pp.

Silander JS, Klepeis DM (1999) The invasion ecology of Japanese barberry (Berberis thunbergii) in the New England landscape. Biological Invasions 1: 189-201. doi:10.1023/A:1010024202294

Sork V (1993) Evolutionary ecology of mast-seeding in temperate and tropical oaks (Quercus spp). Plant Ecology 107: 133-147.

Spira WM, Huq A, Ahmed QS, Saeed YA (1981) Uptake of Vibrio cholerae biotype eltor from contaminated water by Water Hyacinth (Eichornia crassipes). Applied Environmental Microbiology 42: 550-553.

Stirton CH (1977) Some thoughts on the polyploid complex Lantana camara L. (Verbenaceae). In: Annecke DP (Ed) Proceedings $2^{\text {nd }}$ National Weeds Conference of South Africa, Stellenbosch, 321-340.

Syed Z, Guerin PM (2004) Tsetse flies are attracted to the invasive plant Lantana camara. Journal of Insect Physiology 50(1): 43-50. doi:10.1016/j.jinsphys.2003.09.007

Thaman RR (1974) Lantana camara: its introduction, dispersal and impact on islands of the tropical Pacific Ocean. Micronesia 10: 17-39.

Tsuyuzaki S, Kanda F (1996) Revegetation patterns and seedbank structure on abandoned pastures in northern Japan. American Journal of Botany 83: 1422-1428. doi:10.2307/2446097

Turner NJ, Szczawinski AF (1991) Common Poisonous Plants and Mushrooms of North America. Timber Press, Portland, OR, 392 pp. 
Twongo T (1993) Status of the water hyacinth in Uganda. In: Greathead A, de Groot P (Eds) Control of Africa's Floating Water Weeds. Proceedings of a workshop held in Zimbabwe, June 1991. Commonwealth Science Council (CSC) London (United Kingdom). CAB international, Wallingford, 55-57.

USDA, APHIS (2000) Public Law 106-224: Title IV, Sect 402 - Plant Protection Act.

USDA, NCRS (2010) The PLANTS Database. - National Plant Data Center, Baton Rouge. http://plants.usda.gov/java/noxComposite [accessed 25 July 2010]

Verdcourt B (1968) Pontederiaceae. In: Milner-Redhead E, Polhill RM (Eds) Flora of Tropical East Africa. Whitefriars Press LTD, London, 1-8.

Verdcourt B (1989) Nymphaeaceae. In: Polhill RM (Ed) Flora of Tropical East Africa. Balkema, Rotterdam, 1-12.

Washington State Department of Health (2010) Hantavirus factsheet. http://www.doh.wa.gov [accessed 30 July 2010]

Westbrooks RG (1981) Introduction of foreign noxious plants into the United States. Weeds Today 12: 16-17.

Whittaker P (2005) Hardy Bamboos: Taming the Dragon. Timber Press, Portland, OR, 300 pp.

World Health Organization (2010) Media centre: Africa trypanosomiasis (sleeping sickness). http://www.who.int/mediacentre/factsheets/fs259/en

Willett KC (1965) Some observations on the recent epidemiology of sleeping sickness in Nyanza Region, Kenya, and its relation to the general epidemiology of Gambian and Rhodesian sleeping sickness in Africa. Transaction of the Royal Society of Tropical Medicine and Hygiene 59: 374-386. doi:10.1016/0035-9203(65)90055-6

Williams SC, Ward JS, Worthley TE, Stafford KC (2009) Managing Japanese Barberry (Ranunculales: Berberidaceae) Infestations Reduces Blacklegged Tick (Acari: Ixodidae) Abundance and Infection Prevalence With Borrelia burgdorferi (Spirochaetales: Spirochaetaceae). Environmental Entomology 38: 977-84. doi:10.1603/022.038.0404

Williams SC, Ward JS (2010) Effects of Japanese Barberry (Ranunculales: Berberidaceae) Removal and Resulting Microclimatic Changes on Ixodes scapularis (Acari: Ixodidae) Abundances in Connecticut, USA. Environmental Entomology 39: 1911-1921. doi:10.1603/EN10131

Wilson JRU, Ajuonu O, Center TD, Hill MP, Julien MH, Katagira FF, Neuenschwander P, Njoka SW, Ogwang J, Reeder RH, Van T (2007) The decline of water hyacinth on Lake Victoria was due to biological control by Neochetina spp. Aquatic Botany 87: 90-93. doi:10.1016/j.aquabot.2006.06.006

Yates TL, Mills JN, Parmenter CA, Ksiazek TG, Parmenter RR, Vande Castle JR, Calisher CH, Nichol ST, Abbot KD, Yound JC, Morrison ML, Beaty BJ, Dunnum JL, Baker RJ, Salazar-Bravo J, Peters CJ (2002) The ecology and evolutionary history of an emergent disease: Hantavirus Pulmonary Syndrome. BioScience 52: 989-998. doi:10.1641/00063568(2002)052[0989:TEAEHO]2.0.CO;2 